\title{
PELAKSANAAN PERJANJIAN KREDIT DENGAN JAMINAN FIDUSIA PADA BANK PERKREDITAN RAKYAT ( BPR ) WERDHI SEDANA KABUPATEN GIANYAR*
}

\author{
Oleh : \\ Anak Agung Gede Agung Ari Patrama** \\ A.A Gede Agung Darma Kusuma ${ }^{* * *}$ \\ Suatra Putrawan ${ }^{* * * *}$ \\ Hukum Bisnis, Fakultas Hukum, Universitas Udayana
}

\begin{abstract}
ABSTRAK
Perjanjian ialah suatu perikatan yang dilakukan oleh satu pihak dengan pihak pihak lainnya. Hendaknya di dalam suatu perjanjian memuat secara rinci mengenai sebab dan akibat dari diadakannya suatu perjanjian. Begitupula dalam perjanjian jaminan dengan Jaminan Fidusia, segala bentuk yang berkaitan dengan Jaminan Fidusia yang termuat dalam Undang-undang nomor 42 Tahun 1999 tentang Jaminan Fidusia harus dibuat secara rinci dalam perjanjian jaminan tersebut. Pasal 11 ayat (1) Undan-Undang nomor 42 Tahun 1999 menyatakan: "Benda yang dibebani dengan Jaminan Fidusia wajib didaftarkan". Tujuan dari didaftarkanya Jaminan Fidusia tidak lain adalah untuk mendapatkan Sertifikat Fidusia. Sertifikat Fidusiia memiliki kekuatan exsekutorial yang sama dengan putuan pengadilan yang telah mempunyai kekuataan hukum tetap. Di Bank Perkreditan Rakyat Werdhi Sedana Kabupaten Gianyar, menarik diteliti yaitu tentang bagaimana pelaksanaan perjanjian kredit dengan Jaminan Fidusia BPR Werdhi Sedana dan akibat bila tidak didaftarkannya Jaminan Fidusia ke kantor pendaftaran fidusia oleh Bank Perkreditan Rakyat Werdhi Sedana. Penelitian ini menggunakan metode penelitian hukum empiris. Dalam prakteknya perjanjian kredit dengan jaminan fidusia di Bank Perkreditan Rakyat Werdhi Sedana tidak memuat secara rinci tentang Jaminan Fidusia sesuai
\end{abstract}

${ }^{*}$ Makalahari ilmiah ini ditulis dan dikembangkan lebih lanjut dari Skripsi yang ditulis oleh Penulis A.A Gde Agung Ari Patrama atas bimbingan dari Pembimbing Skripsi I A.A Gede Agung Dharmakusuma, SH.,MH. Dan Pembimbing Skripsi II Suatra Putrawan, $\mathrm{SH} . \mathrm{MH}$.

${ }^{* *}$ A.A Gde Agung Ari Patrama, Mahasiswa Fakultas Hukum Universitas Udayana : junk_chana@gmail.com.

${ }^{* * *}$ A.A Gede Agung Dharmakusuma, Dosen Fakultas Hukum Univesitas Udayana.

${ }^{* * * *}$ Suatra Putrawan, Dosen Fakultas Hukum Universita Udayana. 
dengan Undang-Undang Fidusia, melainkan hanya menggunakan perjanjian baku atau perjanjian umum standar. Dalam praktek Jaminan Fidusia, di Bank Perkreditan Rakyat Werdhi Sedana, Jaminan Fidusia tersebut tidak didaftarkan oleh pihak Bank. Sehingga hal tersebut merupakan suatun kerugian bagi Bank karena tidak memiliki kekuatan eksekutorial ketika Debitur sebagai Pemberi Fidusia cidera akan janjinya.

Kata kunci : Perjanjian, Jaminan Fidusia , Bank Perkreditan

\title{
Rakyat
}

\begin{abstract}
An agreement is an agreement made by one party with the other party. Should an agreement contain details about the cause and effect of the agreement. Likewise in the guarantee agreement with Fiduciary Guarantee, all forms relating to the Fiduciary Guarantee contained in Law number 42 of 1999 concerning Fiduciary Guarantees must be made in detail in the guarantee agreement. Article 11 paragraph (1) Laws number 42 of 1999 states: "Items loaded with Fiduciary Guarantees must be registered". The purpose of registering a Fiduciary Guarantee is to obtain a Fiduciary Certificate. The Fiduciary Certificate has the executive power that is the same as the court decision that has permanent legal force. In the People's Credit Bank of Werdhi Sedana, Gianyar Regency, it is interesting to examine the implementation of credit agreements with Fiduciary Guarantees in the Werdhi Sedana Rural Bank and the result if the Fiduciary Guarantee is not registered with the fiduciary registration office by the Rural Bank Werdhi Sedana. This study uses empirical legal research methods. In practice the loan agreement with fiduciary collateral at the Rural Bank Werdhi Sedana does not contain details about the Fiduciary Guarantee in accordance with the Fiduciary Law, but only uses standard agreements or standard general agreements. In the practice of Fiduciary Assurance, at the Rural Bank Werdhi Sedana, the Fiduciary Guarantee is not registered by the Bank. So that this is a loss for the Bank because it does not have executorial power when the Debtor as the Fiduciary Giver is injured in its promise.
\end{abstract}

Keywords: Agreement, Fiduciary Guarantee, Rural Credit Bank 


\section{PENDAHULUAN}

\subsection{LATAR BELAKANG MASALAH}

Melakukan pinjaman kredit di suatu jasa perbankan merupakan suatu pilihan yang harus dilakukan oleh masyarakat mengingat pertumbuhan ekonomi yang semakin pesat sehingga meningkat pula nilai kebutuhan pokok setiap individu yang tidak dapat terpenuhi. Kredit menurut Pasal 1 butir 11 Undang-Undang Nomor 10 Tahun 1998 Tentang Perubahan Atas Undang-Undang Nomor 7 Tahun 1992 Tentang Perbankan adalah : "Penyediaan uang atau tagihan yang dapat dipersamakan dengan itu, berdasarkan persetujuan atau kesepakatan pinjaman untuk melunasi utangnya setelah jangka waktu tertentu dengan pemberian bunga".

Mengacu pada pengertian kredit diatas bahwa prestasi akan terjadi antara nasabah dengan pihak bank atas kredit yang didapat oleh nasabah.Pihak nasabah tidak hanya melunasi hutangnya, tetapi juga disertai dengan pembayaran bunga sesuai dengan perjanjian yang sebelumnya telah disepakati oleh kedua belah pihak. ${ }^{1}$ Nasabah merupakan suatu pihak yang menggunakan jasa perbankan.

Kredit berasal dari kata "credere" yang di kenal dalam Bahasa Yunani dan Romawi yang berarti kepercayaan. Maka dari itu dasar pemberian kredit adalah suatu kepercayaan, yang berarti bahwa seseorang atau suatu badan usaha yang telah mendapatkan fasilitas kredit dari suatu bank, maka orang atau badan usaha tersebut telah mendapatkan kepercayaan dari bank ${ }^{2}$

${ }^{1}$ Hermasyah, 2005, Hukum Perbankan Nasional Indonesia, Kencana Prenadamedia Group, Jakarta h.57

${ }^{2}$ Hasannudin Rahman, 1998, Aspek-Aspek Hukum Pemberian Kredit Perbankan di Indonesia (Panduan Dasar LegaI Officer), PT. Citra Aditya Bakti, Bandung, h.95 
Dalam pemberian kredit oleh Bank, tidak serta merta hanya menggunakan kepercayaan saja, melainkan juga menggunakan suatu perjanjian tertulis berupa perjanjian kredt. Perjanjian kredit adalah suatu perjanjian pokok yang dilakukan disetiap pemberian kredit oleh Bank. Perjanjian tersebut berisikan perikatan dan kesepakatan antar pihak nasabah dengan pihak bank.

Perjanjian diterjemahan dari kata overeenkomst dan verbintenis dalam bahasa Belanda dan Agreement dalam bahasa Inggris. Perjanjian merupakan terjemahan dari Toestemming yang yang dapat diartikan sebagai suatu kata sepakat atau persesuaian kehendak, dalam perjanjian akan mengandung suatu unsure perbuatan, antara satu orang atau lebih terhadap satu orang atau lebih lainnya yang mengikatkan dirinya. Dalam pasal 1313 KUHPerdata yang mengatur tentang perjanjian berbunyi "Suatu perjanjiian adalah suatu perboatan dimana seseorang atau lebih mengikatkan diri terhadap seseorang atau lebih lainnya". Dan Menurut Kamus Hukum , perjanjian adalah peretujuan, pemufakatan antara dua orang/pihak untuk melaksanakan sesuatu. ${ }^{3}$

Perjanjian kredit merupakan suatu perjanjian pokok (prinsipil) yang bersifat riil. Arti riil ialah bahwa terjanjinya perjanjian kredit ditentukan oleh penyerahan uang oleh bank kepada nasabah debitur. Sebagai perjanjian prinsiipil, maka perjanjian jaminan adalah assessornya. Ada dan berakirnya perjanjian jaminan bergantung pada perjanjian pokok. ${ }^{4}$

Perjanjian kredit ini tunduk kepada bagian umum Buku III KUHPerdata dan Undang-undang Perbankan. Dan dalam aspek riil perjanjian kredit tunduk pada Undang-Undang Perbankan dan

${ }^{3}$ Subekti (3) , 2005, Kamus Hukum, Pradnya Paramita , Jakarta, h.89

${ }^{4}$ Hermansyah, Loc.Cit 
ketentuan yang terdapat di dalam model-model perjanjian (standar) kredit yang dipergunakan di lingkungan perbankan, perjanjian kredit dalam aspeknya yang riil ini tidak tunduk pada Bab XIII Buku III BW.

Dalam Undang-Undang Perbankan dengan tegas disebutkan bahwa suatu bank tidak diperbolehkan memberikan kredit tanpa suatu perjanjian secara tertulis. ${ }^{5}$ Maka dari itu perjanjian kredit merupakan suatu syarat utama bagi debitur untuk mendapatkan kredit dari bank yang bertujuan sebagai alat bukti bagi para pihak yang terkait dengan kredit tersebut. ${ }^{6}$

Dalam perjanjian jaminan, salah satu jenis jaminan yang dapat digunakan dalam rangka peminjaman kredit di suatu Bank adalah Jaminan Fidusia. ${ }^{7}$ Pasal 1 Undang-undang Nomor 42 Tahun 1999 tentang Jaminan Fidusia, menyatakan :

"Jaminan Fidusia adalah hak jaminan atas benda bergerak baik yang berwujud maupun tidak berwujud dan benda tidak bergerak khususnya bangunan yang tidak dapat dibebani Hak Tanggungan sebagaimana dimaksud dalam Undang-undang Nomor 4 Tahun 1996 tentang Hak tanggungan yang tetap berada dalam penguasaan Pemberi Fidusia, sebagai angunan bagi pelunasan utang tertentu, yang memberikan kedudukan yang diutamakan kepada Penerima Fidusia terhadap kreditor lainnya".

Undang-Undang Fidusia telah jelas menyatakan bahwa segala bentuk benda yang dibebankan dengan Jaminan Fidisia wajib diddaftarkan ke Kantor Pendaftaran Fidusia. sebelum didaftarkan

5 Widjanarto, 2003, Hukum dan Ketentuan Perbankan Di lndonesia, Grafiti, Jakarta , h.101

${ }^{6}$ Sentosa Sembiring, 2012, Hukum Perbangkan Edisi Revisi, CV. Mandar Maju , Bandung , h. 194

${ }^{7} \mathrm{Ni}$ Putu lndianita Cahyanti, Marwanto, 1 Nyoman Mudana, "Pelaksanaan Kewajiban Pemberi Fidusia Sebagai yang Menguasai Benda Jaminan Fidusia pada PT IndoMobilFinance Indonesia Cabang Tabanan" Kertha Semaya, Vol.07, No.01, Maret 2019, Hal 2-3, https://ojs.unud.ac.id/index.php/kerthasemaya/article/view/47843, diakses tanggal 23 April 2019, Pukul 21.40 WITA 
Jaminan Fidusia terlebih dahulu dibebankan dengan Akta notaries. Setelah itu Akta Fidusia didaftarkan ke Kantor Pendaftaran Fidusia untuk mendapatkan Sertifikat Fidusia. Sertifikat ini mempunyai kekuatan eksekutorial yang sama dengan putusan pengadilan yaang telah memperoleh kekuatan hukum tetap yang telah diatur dalam Pasal 5 ayat 2 Undang-undang Fidusia. Yang berguna untuk melakukan eksekusi Jaminan Fidusia. Jadi jelas bahwa jika benda yg akan dibebankan dengan fidusia tersebut tidak didaftarkan oleh bank, maka dalam hal debitur cidera akan janjinya, maka pihak bank tidak mempunyai hak eksekusitorial untuk melakukan eksekusi terhadapan objek jaminan sesuai dengan Undang-Undang Fidusia.

Dalam prakteknya, banyak jasa perbankan lalai terhadap UU No. 42 Tahun 1999 tentang Jaminan Fidisia terutama pada pendaftaran Jaminan Fidusia. dimana banyak Bank yang tidak mendaftarkan Jaminan Fidusia dengan berbagai macam alasan, salah satu diantaranya adalah biaya. Padahal dalam hal ini, kerugian ada di pihak Bank. Karena akan menimbulkan akibat hukum jika jaminan tersebut tidak didaftarkan. ${ }^{8}$ Diantaranya yaitu pihak Bank tidak memiliki kekuatan eksekutorial untuk menjalankan eksekusi terhadap jaminan ketika debitur cidera janji.

Salah satu jasa perbankan yang menawarkan pinjaman kredit dengan jaminan berupa Jaminan Fidusia adalah BPR Werdhi Sedana Kabupaten Gianyar. Pasal 1 angka 4 Undang-Undang Nomor 10 Th. 1999 Menyebutkan bahwa : "Bank Perkrediitan Rakyat adalah bank yang melaksanakan kegiatan usaha secara konvensial atau berdasarkan prinsip syariah yang dalam kegiatanya

8 Ni Kadek Dwi Fitri SiIvia Dewi, Marwanto, A.A Sri lndrawati, 2019, "PeIaksanaan Jaminan Fidusia Pada Lembaga Perkreditan Desa (LPD) lntaran di Desa Pekraman Sanur", Kertha Semaya, Vol.07, No.01, Maret 2019, Hal 6, https://ojs.unud.ac.id/index.php/kerthasemaya/article/view/46438, diakses tanggal 23 April 2019, Pukul 21.30 WITA. 
tidak memberikan jasa dalam lalui lintas pembayaran. BPR Werdhi Sedana merupakan Bank milik permerintah Kabupaten Gianyar. Dalam prakteknya memberikan suatu Kredit dengan jaminan berupa Jaminan Fidusiia, BPR Werdhi Sedana hanya membebankan Jamuinan Fidusia dengan Akta Notaris saja tanpa Mendaftarkan Jaminan Fidusia tersebut. Yang sehingga membuat penulis tertarik dan berniat untuk melakukan suatu penelitian tentang bagaimana pelaksanaan perjanjian kredit dengan Jaminan Fidusia di BPR Werdhi Sedana dan akibat hukum bila Jamiinan Fidusia tersebut tidak didaftarkan oleh BPR Werdhi Sedana.

\subsection{Rumusan Masalah}

1. Bagaimanakah pelaksanaan perjanjian kredit dengan Jaminan Fidusia yang dilakukan oleh Bank Perkreditan Rakyat ( BPR ) Werdhi Sedana Kabupaten Gianyar ?

2. Apakah akibat hukum bila Jaminan Fidusia tidak didaftarkan oleh Bank Perkreditan Rakyat (BPR) Werdhi Sedana?

\subsection{Tujuan}

Tujuan dari penulisan ini adalah untuk mengetahui pelaksanaan perjanjiian kredit dengan Jaminan Fidussia di BPR Werdhi Sedana dan mengetahui akiba hukum bila jaminann Fidusia tidak didaaftarkan oleh BPR Werdhi Sedana.

\section{ISI MAKALAH}

\subsection{Metode Penelitian}

Penulisan penelitian ini menggunakan metode penelitian hukum empiris. Penelitian hukum empiris merupakan penelitian hukum mengenai pemberlakuan atau implementasi ketentuan hukum (kodifikasi, undang-undang atau kontrak) secara in action pada setiap peristiwa hukum tertentu yang terjadi di dalam masyarakat yang berfokus pada penerapan atau implementasi 
ketentuan normative pada peristiwa hukum tertentu. ${ }^{9}$ Penelitian dilakukan dengan cara pendekatan terhadap fakta-fakta di lapangan dan pendekatan perundang-undangan yang bersifat deskriptif. Data yang kemudian di kumpulkan, baik secara sekunder maupun primer yang merupakan hasil dari studi dokumen dan wawancara kemudian data tersebut di oleh secara kualitatif.

\subsection{Hasil dan Pembahasan}

\subsubsection{Pelaksanaan Jaminan Kredit dengan Jaminan Fidusia pada Bank Perkreditan Rakyat (BPR) Werdhi Sedana Kabupaten Gianyar}

Pada umumnya suatu perjanjian adalah merupakan suatu perikatan. Adapaun syarat dari Sahnya suatu perjanjian yang telah tercantum pada Pasal 1320 KUHPer yang diantaranya adalah :

1. Sepakat mereka yang mengikatkan dirinya,

2. Kecakapan untuk membuat suatu perikatan

3. Suatu hal tertentu;

4. Suatu sebab yang halal

Mengacu pada Perjanjian Jaminan dengan Jaminan Fidusia, syarat dari sahnya perjanjian. Maka seharusnya dalam suatu perjanjian Jaminan Fidusia harus memuat secara rinci tentang bagaimana Jaminan Fidusia tersebut sesuai dengan Undang_undang Fidusia.

Berdasarkan keterangan yang diperoleh melalui hasil wawancara kepada pegawai BPR Werdhi Sedana, Dalam prakteknya perjanjian kredit dengan perjanjian jaminan berupa jaminan fidusia tersebut menggunakan perjanjian Jamian secara umuum, dimana perjanjian jaminan secara umum dimaksudkan sebagai perjanjian jaminan dalam arti luas yang tidak mengacu pada satu jenis

${ }^{9}$ AbduIkadir Muhammad, 2004, Hukum dan PeneIitian Hukum, PT Citra Aditya Bakti, Bandung, h.134 
jaminan. Yang seharusnya perjanjian kredit dengan perjanjian jaminan dengan jaminan berupa Jaminan Fidusia tersebut memuat secara rinci tentang Jaminan Fidusia sesuai dengan UU Fidusia

\subsubsection{Akibat Hukum Bila Jaminan Fidusia TIdak Didaftakan Oleh Bank Perkreditan Rakyat (BPR) Werdhi Sedana Kabupaten Gianyar}

Berdasarkan Pasal 11 ayat (1) Undang-Undang Nomor 42 Tahun 1999 tentang Jaminan Fidusia menyatakan : "Benda yang dibebani dengan Jaminan Fidusia wajib didaftarkan". Pendaftaran Jaminan Fidusia dilakukan di Kantor Pendaftaran Fidusia . Sebelum didaftarkan terlebih dahulu Jaminan di bebankan dengan Aktaa Notariis. Hal ini adalah salah satu persyaratan pendaftaran Jaminan Fidusia yang dimuat dalam Pasal 13 ayat (2) Undang Undang Fidusia. Pendaftaran Jaminan Fidusia ini bertujuan untuk mendapatkan Sertifikat Fidusia. Sertfikat Fidusia ini mempunyai suatu kekuatan yaitu kekuatan eksekutorial yang sama dengan putusan pengadilan yang telah memiliki kekuatan hokum tetap. Dengan memiliki sertifikat tersebut, maka Penerima Fidusia mempunyai Hak untuk menjual Benda yang menajdi Obyek Jaminan Fidusia atas Kehendaknya sendiri ketika Pemberi Fidusia cidera janji.

Berdasarkan keterangan yang diperoleh dari hasil wawancara dengan pegawai BPR Werdhi Sedana, dalam prakteknya, di BPR Werdhi Sedana Jaminan Fidusia merupakan salah satu jenis jaminan yang dapat digunakan untuk mendapatkan suatu kredit di BPR Werdhi Sedana. Di BPR Werdhi Sedana, benda yang dapat dijadikan sebagai Objek Jaminan Fidusia adalah benda bergerak baik yang berwujud ataupun tidak berwujud dan benda yang tidak bergerak khususnya bangunan yang tidak dapat dibebani dengan Hak Tanggungan. 
Tentu saja dalam pemberian kredit dengan jaminan berupa Jamiinan Fidusia, sesudah kredit di cairkan oleh BPR Werdhi Sedana ,Jaminan Fidusia tersebut akan dibebankan dengan Akta Notaris yang bertujuan untuk mengalihkan hak kepemilikan Jaminan Fidusia tersebut dari pihak Pemberi Fidusia (Debitur) kepada pihak Penerima Fidusia ( Bank) dalam rangka sebagai jaminan atas perikatan yang dibuat oleh debitur dengan Bank. Pembebanan Akta Notaris ini dilakukan di Kantor Notaris Luh Eka Nadi Antari, S.H, M.kn yang beralamat di Jl. Raya Sukawati No. 45A, Sukawati, Kabupaten Gianyar.

Setelah dibebankan dengan Akta Notaris, Kredit dengan plafon diatas Rp. 25.000.000,00 , Jaminan tersebut akan didaftaarkan ke Kantor Pendaftaran Fiidusia dalam Departemen Hukum dan Ham Provinsi Bali. Dengan memenuhi persyaratan tentang pendaftaran yang telah dimuat di dalam Undang-Undang Fidusia. Sedangkan kredit dengan plafon dibawah RP. 25.000.000,00 tidak didaftarkan oleh pihak BPR Werdhi Sedana karena alasan biaya dan hanya berkekuatan hukum sampai dengan Akta Notaris saja.

Dalam tahap mengeksekusi Jamiinan yang telah dibebankan dengan Fidusiia ketika Debitur dalam hal ini Pemberi Fidusia cidera janji,pembahasan kali ini berdasarkan keterangan yang diperoleh melalui hasil wawancara dengan Bapak I Wayan Rapeg Eka Antara ( Kepala Bagian Kredit ) pada tanggal 17 Januari 2019. Pada BPR Werdhi Sedana sebelumnya belum pernah melakukan eksekusi terhadap Jaminan Fidusia. karena selama ini yang menjadi nasabah debitur dalam BPR Werdhi Sedana menjalankan Prestasi sesuai dengan apa yang telah diperjanjikan. Dan adapun dengan nasabah-nasabah yang cidera akan janjinya tetapi tidak dalam tahap yang serius, akan diselesaikan secara mediasi yang dilakukan pihak Bank dengan pihak debitur agar untuk yang sebelumnya 
nasabah cidera janji dan sesudah mediasi akan kembali ke prestasi yang sebelumnya telah diperjanjikan.

Namun dengan nasabah yang cidera janji dengan tahap yang serius, dalam hal ini kredit macet, BPR Werdhi Sedana memiliki prosedur dan tahapan dalam melakukan suatu eksekusi. Diantaranya yang pertama adalah dilakukan Mediasi, mediasi bertujuan untuk penyelesaikan permasalahan tersebut secara kekeluargaan. Jika dalam tahap ini ternyata gagal, kemudian tahap selanjutnya Bank akan melakukan Eksekusi berupa penarikan Objek Jaminan dan setelah itu akan menjual Objek Jaminan dengan dilakukan Penjualan secara bersama. Penjualan secara bersama ini adalah kedua pihak sama-sama berusaha untuk menjual Objek Jaminan. Hasil dari penjualan tersebut nantinya akan digunakan untuk membayar sisa utang Debitur terhadap Bank. Dan jika hasil penjualan tersebut lebih dari sisa hutang debitur terhadap bank, maka sisa hasil penjualan akan dikembalikan kepada debitur. Dan jika dalam tahap ini juga gagal, tahap akhir yang dilakukan adalah dengan cara pelelangan. Jika hasil dalam proses pelelangan ini melebihi sisa hutang debitur terhadap Bank, maka sisa hasil pelelangan akan dikembalikan kepada debtur . Dan apabila dari pelelangan ternyata kurang dari sisa hutang debitur terhadap Bank, maka sisa Hutang tersebut masih dalam tanggung jawab debitur sesuai dengan perjanjian yang telah dibuat.

\section{KESIMPULAN}

Pelaksanaan perjanjian Kredit dengan perjanjian jaminan berupa Jaminan Fidusia di Bank Perkreditan Rakyat Werdhi Sedana dilakukan oleh pihak Bank dengan pihak debitur. Perjanjian dilakukan sebelum pihak Bank mencairkan kredit 
tersebut. Perjanjian kredit dengan perjanjian Jaminan dengan Jaminan Fidusia di BPR Werdhi Sedana menggunakan jenis perjanjian Baku. Yang dimana perjanjian jaminan tersebut membahas perjanjian jaminan secara umum tanpa memuat Jaminan Fidusia secara rinci berdasarkan Undang-Undang Nomor 42 Tahun 1999 tentang Jaminan Fidusia dan Akibat Hukum dari tidak didaftarkannya Jaminan Fidusia oleh BPR Werdhi Sedana adalah lemah dalam melakukan eksekusi terhadap Objek Jaminan Fidusia karena dalam hal Jaminan Fidusia tidak didaftarkan maka tidak akan mendapatkan Sertifikat Fidusia yang memiliki kekuatan eksekutorial yang sama dengan putusan pengadilan yang sudah berkekuatan hukum tetap.

\section{DAFTAR PUSTAKA}

\section{BUKU}

Hermansyah, 2005, Hukum Perbankan Nasional Indonesia, Kencana Prenadamedia Group, Jakarta

Muhammad, Abdulkadir, 2004, Hukum dan Penelitian Hukum, PT Citra Aditya Bakti, Bandung

Rahman, Hasanuddin, 1998, Aspek-Aspek Hukum Pemberian Kredit Perbankan di Indonesia (Panduan Dasar Legal Officer), PT. Citra Aditya Bakti, Bandung

Sembiring, Sentosa, 2012, Hukum Perbankan Edisi Revisi, CV. Mandar Maju, Bandung

Subekti , 2005, Kamus Hukum, Pradnya Paramita , Jakarta

Widjanarto, 2003, Hukum dan Ketentuan Perbankan Di Indonesia, Grafiti, Jakarta

\section{JURNAL}

Ni Kadek Dwi Fitri Silvia Dewi, Marwanto, A.A Sri Indrawati, 2019, "Pelaksanaan Jaminan Fidusia Pada Lembaga Perkreditan Desa 
(LPD) Intaran di Desa Pekraman Sanur", Kertha Semaya, Vol.07, No.01, Maret 2019, Hal https://ojs.unud.ac.id/index.php/kerthasemaya/article/view/464 $\underline{38}$, diakses tanggal 23 April 2019, Pukul 21.30 WITA.

Ni Putu Indianita Cahyanti, Marwanto, I Nyoman Mudana, "Pelaksanaan Kewajiban Pemberi Fidusia Sebagai yang Menguasai Benda Jaminan Fidusia pada PT IndoMobilFinance Indonesia Cabang Tabanan" Kertha Semaya, Vol.07, No.01, Maret 2019, Hal 2-3, https://ojs.unud.ac.id/index.php/kerthasemaya/article/view 147843, diakses tanggal 23 April 2019, Pukul 21.40 WITA

\section{PERATURAN PERUNDANG-UNDANGAN}

Indonesia, Undang-Undang Dasar Negara Republik Indonesia Tahun 1945

Indonesia, Undang-Undang Republik Indonesia Nomor 10 Tahun 1998 Tentang Perubahan Atas Undang-Undang Nomor 7 Tahun 1992 Tentang Perbankan

Kitab Undang-Undang Hukum Perdata, B.W. Burgerlijk Wetboek diterjemahkan oleh Soesilo, Pramudji R.

Indonesia, Undang-Undang Republik Indonesia Nomor 42 Tahun 1999 Tentang Jaminan Fidusia (Lembaran Negara Republik Indonesia Tahun 1992 Nomor 166, Tambahan Lembaran Negara Republik Inpdonesia Nomor 3889) 